\title{
Survey for the Three Major Leafroll Disease-Associated Viruses in Finger Lakes Vineyards in New York
}

\author{
M. Fuchs, Department of Plant Pathology and Plant-Microbe Biology, Cornell University, New York State Agricul- \\ tural Experiment Station, Geneva, NY 14456; T. E. Martinson, Department of Horticultural Sciences, Cornell Uni- \\ versity, New York State Agricultural Experiment Station, Geneva, NY 14456; G. M. Loeb, Department of Entomol- \\ ogy, Cornell University, New York State Agricultural Experiment Station, Geneva, NY 14456; and \\ H. C. Hoch, Department of Plant Pathology and Plant-Microbe Biology, Cornell University, New York State Agri- \\ cultural Experiment Station, Geneva, NY 14456
}

\begin{abstract}
Fuchs, M., Martinson, T. E., Loeb, G. M., and Hoch, H. C. 2009. Survey for the three major leafroll disease-associated viruses in Finger Lakes vineyards in New York. Plant Dis. 93:395401.

Vineyards in the Finger Lakes region in New York were surveyed for the three major viruses associated with leafroll disease, i.e., Grapevine leafroll-associated virus 1 (GLRaV-1), Grapevine leafroll-associated virus 2 (GLRaV-2), and Grapevine leafroll-associated virus 3 (GLRaV$3)$. Target viruses were detected in nearly two-thirds $(68 \%, 65$ of 95) of the vineyard blocks surveyed by enzyme-linked immunosorbent assay. Single infections by GLRaV-1, GLRaV-2, and GLRaV-3 occurred in 10\% (113 of 1,124), 3\% (36 of 1,124), and 15\% (173 of 1,124) of the samples tested, respectively, whereas mixed infections affected $3.6 \%$ (40 of 1,124) of them, essentially with GLRaV-1 and GLRaV-3 (2.5\%, 28 of 1,124). Presence of the target viruses was confirmed in selected samples by reverse transcription-polymerase chain reaction and sequencing. Comparative analysis indicated moderate to high nucleotide sequence identities in the second diverged copy of the GLRaV-1 coat protein gene (81.0 to $86.7 \%$ ), GLRaV-2 coat protein gene (87.6 to $99.2 \%$ ), and GLRaV-3 heat shock protein 70 homologue gene (91.5 to $98.3 \%$ ) of New York isolates with corresponding virus reference strains. The prevalence of the three major leafroll disease-associated viruses in Finger Lakes vineyards results likely from poor sanitary status of planting materials, stressing the need to reinstate a certification program in New York.
\end{abstract}

Leafroll disease is an important and widespread viral disease of grapevines. It occurs in all the major grape-growing regions of the world and can affect Vitis spp., interspecific hybrids, and rootstocks $(8,15,25,27)$. In late summer and fall, older leaves of leafroll-affected vines are cupped with principal veins often remaining green. Symptoms are usually conspicuous in redfruited cultivars of $V$. vinifera, with interveinal leaf tissue becoming distinctly red in addition to cupping. In white-fruited $V$. vinifera cultivars, symptoms are less pronounced, consisting of a slight chlorosis in addition to cupping. V. labrusca, interspecific hybrids, and rootstocks usually are symptomless $(15,25,27)$. Leafroll causes significant yield losses (up to 30 to $50 \%$ ) and delays fruit ripening. Reduced soluble solids and increased titratable acidity often are reported in fruit juice. Berries of red-fruited cultivars may show pale

Corresponding author: M. Fuchs

E-mail:mf13@cornell.edu

Accepted for publication 23 December 2008.

doi:10.1094/PDIS-93-4-0395

(C) 2009 The American Phytopathological Society coloring due to reduced skin anthocyanin pigments $(8,15,25,27)$.

To date, 10 different phloem-limited filamentous viruses identified as grapevine leafroll-associated viruses (GLRaVs) have been isolated and characterized from leafroll-infected grapevines $(1,26,27)$. These viruses are unrelated serologically and belong to the family Closteroviridae. All GLRaVs are readily transmitted by propagation and grafting, and some of them (Grapevine leafroll-associated virus 1 [GLRaV-1], Grapevine leafroll-associated virus 3 [GLRaV-3], Grapevine leafrollassociated virus 5 [GLRaV-5], and Grapevine leafroll-associated virus 9 [GLRaV9]) are also transmitted by several species of mealybugs and soft scale insects (17,27,32). GLRaV-1, Grapevine leafrollassociated virus 2 (GLRaV-2), and GLRaV-3 are often prevalent in $V$. vinifera affected by leafroll disease $(13,39)$.

The wine and grape industry in New York ranks third behind California and Washington, providing $2.6 \%$ of U.S. grape production (3). There are four major grape growing areas in New York: Lake Erie and the Niagara escarpment, Finger Lakes, Hudson River, and Long Island (Fig. 1). Three-fourths of the grape production in New York is for juice and other products, and one-fourth is for wine production. Juice is produced mainly from $V$. labrusca, whereas wines are produced from $V$. vinifera, V. labrusca, and interspecific hybrids. Most $V$. vinifera in New York are grown in Long Island and the Finger Lakes region.

The occurrence of leafroll disease has been reported in $V$. vinifera (18) and $V$. labrusca (37) in New York. Also, the fulllength genomic sequences of GLRaV-2 and GLRaV-3 have been determined from New York isolates $(22,23,29,38)$. Amidst advances on disease presence and viral genome structure and expression, little is known on the incidence and prevalence of GLRaV-2 and GLRaV-3 in vineyards in New York. Similarly, no information is available on the presence of GLRaV-1 in New York vineyards. Therefore, we examined the status of these three major leafroll-associated viruses in Finger Lakes vineyards in New York. Here we report on the prevalence of GLRaV-1, GLRaV-2, and GLRaV-3 in the majority of vineyard blocks of $V$. vinifera and interspecific hybrids that were surveyed. The implications of our findings will be discussed in terms of the need to reinstate a grape certification program in New York for improving the sanitary status of planting materials.

\section{MATERIALS AND METHODS}

Vineyards and leaf sample collection. Ninety-five vineyard blocks of $V$. vinifera and interspecific hybrids were surveyed in this study. A $4 \times 5$ quadrat sampling strategy with a stratified regular quadrat distribution was used to collect leaf samples from the lower vine canopy in late August through early October of 2006. Leaf samples were collected from each quadrat, four quadrats per row, every five rows, for a maximum of 20 quadrats per vineyard block. Composite samples of three leaves per vine and five vines per quadrat, making a total of 15 leaves per sample, were collected and further tested for the presence of the three target viruses, i.e., GLRaV-1, GLRaV-2, and GLRaV-3.

Virus detection by double antibody sandwich-enzyme-linked immunosorbent assay (DAS-ELISA). GLRaV-1, GLRaV-2, and GLRaV-3 were detected by DAS-ELISA in leaf extracts with specific 
antibodies (Bioreba, Reinach, Switzerland). A portion of 15 stacked leaves was torn $(0.5 \mathrm{~g})$ and ground in $200 \mathrm{mM}$ Tris$\mathrm{HCl}, \mathrm{pH} 8.2,140 \mathrm{mM} \mathrm{NaCl}, 2 \%$ polyvinylpyrrolidone 40 , and $0.05 \%$ Tween 20 $(35,39)$ at a $1: 10$ ratio (wt/vol) using a semi-automated ball-bearing HOMEX tissue homogenizer (Bioreba). Test conditions were according to the manufacturer's instructions (Bioreba). Substrate ( $p$-nitrophenylphosphate) hydrolysis was recorded at $405 \mathrm{~nm}$ with an absorbance BioTek ELx808 microplate reader (BioTek, Winooski, VT). Samples were considered positive if their optical density $\left(\mathrm{OD}_{405 \mathrm{~nm}}\right)$ readings were at least twice those of healthy controls.

Prior to the survey, the detection thresholds of GLRaV-1, GLRaV-2, and GLRaV3 in DAS-ELISA were determined by testing serial dilutions of virus-infected leaf extracts prepared in leaf extracts from healthy vines to validate the sample collection strategy. Detection threshold experiments were replicated three times for each virus with different infected vines.

Virus detection by reverse transcription-polymerase chain reaction (RTPCR). Some of the grapevine leaf samples that tested positive for GLRaV-1, GLRaV2, and GLRaV-3 in DAS-ELISA were further assayed by RT-PCR. Fresh leaf tissue $(100 \mathrm{mg})$ from single leaves was placed in a $2.0-\mathrm{ml}$ microfuge tube, dipped in liquid nitrogen, and disrupted with a TissueLyser homogenizer (Qiagen, Valencia, CA) for $2 \mathrm{~min}$ at $30 \mathrm{MHz}$ in the presence of one stainless steel bead $(5 \mathrm{~mm}$ diameter). Total RNA was extracted from homogenized material using the RNeasy Mini Plant kit (Qiagen).

A segment of the second diverged copy of the coat protein $(\mathrm{CPd} 2)$ gene of GLRaV1 (open reading frame 6), coat protein $(\mathrm{CP})$ gene of GLRaV-2 (open reading frame 6), and heat shock protein 70 homologue (HSP70h) gene of GLRaV-3 (open reading frame 4) was characterized by RT-PCR from total RNA. Primers reported previously for GLRaV-1 (28), GLRaV-2 (4), and GLRaV-3 (28) were used. In addition, a primer pair specific to the ribulose 1,5bisphosphate carboxylase chloroplast gene (Rbcl) of Vitis vinifera (NC_007957.1) was designed (forward primer 5' TACTTG AATGCTACTGCAG $3^{\prime}$ and reverse primer 5' CTGCATGCATTGCACGATC 3') and used as internal control to amplify the

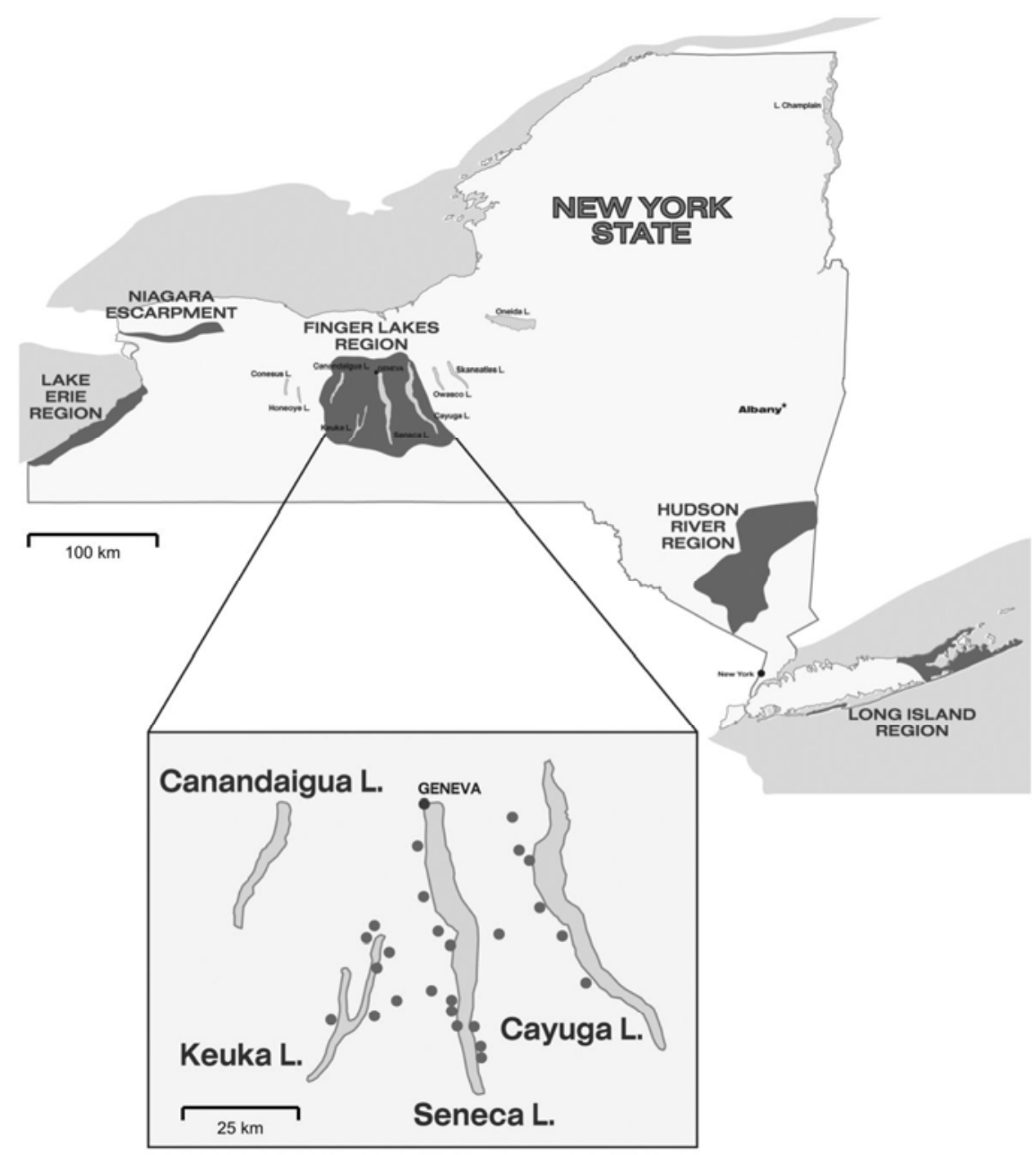

Fig. 1. Map of the four major grape growing areas in New York State with the location of 25 farms in the Finger Lakes region for which vineyard blocks were surveyed for the three major viruses associated with grapevine leafroll disease. corresponding mRNA in standard and multiplex RT-PCR. The Vitis sp. Rbcl primers were designed based on $\mathrm{Rbcl}$ primers of Prunus persica (GenBank accession no. AF206813) (31). Alternatively, primers to the Vitis 18S ribosomal RNA were used as internal control in RT-PCR assays (14).

One-step RT-PCR was carried out using the Access System (Promega, Madison, WI) with Avian myeloblastosis virus RTase, Tfl DNA polymerase, and 50 pmoles of specific primers in a $50-\mu$ l final volume according to the manufacturer's protocol. Single-tube RT-PCR used a 45min heating step at $45^{\circ} \mathrm{C}$ and a 2-min heating step at $94^{\circ} \mathrm{C}$, followed by 45 cycles of $1 \mathrm{~min}$ melting at $94^{\circ} \mathrm{C}, 1 \mathrm{~min}$ annealing at $50^{\circ} \mathrm{C}$, and 2 min elongation at $68^{\circ} \mathrm{C}$, with a final extension of $7 \mathrm{~min}$ at $68^{\circ} \mathrm{C}$. The reaction products of standard and multiplex assays were resolved by electrophoresis in 1.5 and $2 \%$ agarose gels, respectively, in $90 \mathrm{mM}$ Tris-borate, 2 mM EDTA, $\mathrm{pH} 8.0$, and subsequently visualized under UV light after staining with ethidium bromide.

Viral sequence determination and analysis. DNA amplicons obtained by RTPCR were extracted from agarose gels with the QIAquick Gel Extraction kit (Qiagen) and sequenced bidirectionally using the Big Dye Terminator kit, AmpliTaq-FS DNA polymerase, and an Applied Biosystem Automated 3730xl DNA Analyzer at the DNA Sequencing facility at Cornell University in Ithaca, NY. Sequences were analyzed and compared using the DNASTAR Lasergene v7.2 software package. Viral strains used as reference in comparative sequence analysis were GLRaV-1 strain BL4 from $V$. vinifera cv. Sultana (GenBank accession no. AF195822) (12), GLRaV-2 strain PN from $V$. vinifera $\mathrm{cv}$. Pinot noir (GenBank accession no. AF039204) (38), and GLRaV-3 strain NY-1 from $V$. vinifera cv. Pinot noir (GenBank accession no. AF037268) $(22,23)$. The program CLUSTAL W was used for alignment of nucleotide sequences (33). Phylogenetic relationships were determined with the neighbor-joining method (30).

\section{RESULTS}

Ninety-five vineyard blocks from 25 grape growers were surveyed for GLRaV1, GLRaV-2, and GLRaV-3 in the Finger Lakes region in New York (Fig. 1). Vineyard blocks were randomly selected without prior knowledge of their sanitary status. Eighty vineyard blocks were established with $V$. vinifera and 15 with interspecific hybrids (Table 1). They spanned from the western side of Keuka Lake to the western shores of Cayuga Lake, including both sides of Seneca Lake (Fig. 1). The area surveyed covered about $2,500 \mathrm{~km}^{2}$.

Prior to the survey, the detection thresholds of GLRaV-1, GLRaV-2, and GLRaV3 in DAS-ELISA were assessed in order to 
validate our sample collection strategy. GLRaV-1, GLRaV-2, and GLRaV-3 were detected in $1 / 1,280,1 / 320$, and $1 / 640$ dilutions of leaf extracts with absorbance values ranging from 0.179 to $0.194,0.126$ to 0.198 , and 0.138 to 0.177 , respectively, after $4 \mathrm{~h}$ of substrate hydrolysis. Healthy controls had absorbance values of 0.011 to 0.014. These dilution endpoints were equivalent to one infected leaf in 72,54 , and 64 healthy leaves for GLRaV-1, GLRaV-2, and GLRaV-3, respectively. These data indicated that the three target viruses could confidently be detected if one virus-infected leaf was mixed with 14 healthy leaves. Therefore, composite samples consisting of 15 leaves were collected from five vines and processed by DASELISA.

Of the 95 vineyard blocks surveyed, nearly two-thirds $(68 \%, 65$ of 95$)$ had at least one of the three target viruses, as shown by DAS-ELISA (Table 1). Virus incidence was slightly higher in blocks of $V$. vinifera $(71 \%, 55$ of 80$)$ than in blocks of interspecific hybrids $(63 \%, 10$ of 15$)$ (Table 1). A good relationship was evident between leafroll disease symptom expression and virus detection in blocks of $V$. vinifera, especially those of red-berried cultivars (data not shown). Our results were consistent with a prevalence of GLRaV-1, GLRaV-2, and/or GLRaV-3 in the majority of Finger Lakes vineyards surveyed.

Virus incidence as percentage of quadrats infected per vineyard block was high to extremely high in the majority of blocks surveyed $(40 \%, 38$ of 95$)$, while a moderate and low incidence was found in $21 \%$ (20 of 95) and 7\% (7 of 95) of them, respectively (Table 2). Of the 1,124 samples tested (pooled 15 leaves from a quadrat of five vines), 362 (32\%) were positive for at least one of the three target viruses, including $173(15 \%)$ for GLRaV-3, $113(10 \%)$ for GLRaV-1, and 36 (3\%) for GLRaV-2 (Table 3). Single infection occurred in $29 \%$ (322 of 1,124) of the samples tested and mixed infection in $3.6 \%$ (40 of 1,124), essentially with GLRaV-1 and GLRaV-3 (Table 3). The remaining 762 (68\%) samples tested were negative for GLRaV-1, GLRaV-2, and GLRaV-3. DAS-ELISA data were also consistent with a similar distribution of target viruses in $V$. vinifera and interspecific hybrids, with GLRaV-1 and GLRaV-3 being the most prevalent both in single and mixed infections (data not shown).

RT-PCR was used to confirm the presence of the three target viruses in selected samples (Fig. 2). DNA products of the expected size were obtained in total RNA from grapevine leaves infected with GLRaV-1 (401 bp), GLRaV-2 (515 bp), and GLRaV-3 (546 bp). In addition, mixed virus infection was shown in single vines, confirming DAS-ELISA data obtained with leaf material pooled from several
Table 1. Detection of Grapevine leafroll-associated virus 1 (GLRaV-1), Grapevine leafroll-associated virus 2 (GLRaV-2), and Grapevine leafroll-associated virus 3 (GLRaV-3) in vineyard blocks in the Finger Lakes region in New York

\begin{tabular}{lccc}
\hline & \multicolumn{2}{c}{ Number of vineyard blocks } & \\
\cline { 2 - 3 } Genotype/cultivar & Infected $^{\mathbf{a}}$ & Tested & \% Infection \\
\hline Vitis vinifera & & & \\
Cabernet Franc & 9 & 15 & 60 \\
Cabernet Sauvignon & 4 & 4 & 100 \\
Carmine & 0 & 1 & 0 \\
Chardonnay & 7 & 10 & 70 \\
Gewurztraminer & 1 & 1 & 100 \\
Lemberger & 7 & 10 & 70 \\
Merlot & 4 & 5 & 80 \\
Pinot gris & 1 & 2 & 50 \\
Pinot noir & 14 & 20 & 70 \\
Riesling & 5 & 9 & 56 \\
Rkatsiteli & 2 & 2 & 100 \\
Sangiovese & 1 & 1 & 100 \\
$\quad$ Subtotal & 55 & 80 & 71 \\
Interspecific hybrids & & & \\
Chambourcin & 0 & 1 & 0 \\
De Chaunac & 1 & 1 & 100 \\
Landot noir & 1 & 1 & 100 \\
Noiret & 0 & 1 & 0 \\
Rougeon & 1 & 1 & 100 \\
Seyval & 3 & 4 & 75 \\
Vignoles & 4 & 6 & 67 \\
Subtotal & 10 & 15 & 63 \\
Total & 65 & 95 & 68 \\
\hline
\end{tabular}

${ }^{\text {a }}$ Data represent number of vineyard blocks for which samples tested positive in double antibody sandwich-enzyme-linked immunosorbent assay for one of the three target viruses, GLRaV-1, GLRaV-2, and/or GLRaV-3.

Table 2. Incidence of Grapevine leafroll-associated virus 1 (GLRaV-1), Grapevine leafroll-associated virus 2 (GLRaV-2), and Grapevine leafroll-associated virus 3 (GLRaV-3) in Finger Lakes vineyard blocks

\begin{tabular}{lcc}
\hline & \multicolumn{2}{c}{ Number of vineyard blocks } \\
\cline { 2 - 3 } Virus incidence $(\%)^{\mathbf{a}}$ (category) & Tested & Infected (\%) \\
\hline 0 (none) & 30 & 32 \\
$1-10$ (low) & 7 & 7 \\
$11-20$ (moderate) & 20 & 21 \\
$21-50$ (high) & 20 & 21 \\
$51-90$ (very high) & 14 & 15 \\
$91-100$ (extremely high) & 4 & 4 \\
Total & 95 & 100 \\
\hline
\end{tabular}

a Data represent number of quadrats per vineyard block in which samples infected by GLRaV-1, GLRaV-2, and/or GLRaV-3 were detected by double antibody sandwich-enzyme-linked immunosorbent assay over the number of quadrats tested. Number of quadrats tested per block ranged from 4 to 20 depending on size of the vineyard block surveyed.

Table 3. Rates of single and mixed infections by Grapevine leafroll-associated virus 1 (GLRaV-1), Grapevine leafroll-associated virus 2 (GLRaV-2), and/or Grapevine leafroll-associated virus 3 (GLRaV-3) in grapevine leaf samples (pooled 15 leaves from a five-vine quadrat) from Finger Lakes vineyards

\begin{tabular}{lcc}
\hline & \multicolumn{2}{c}{ Virus-infected samples } \\
\cline { 2 - 3 } Virus combination & Infected/tested $^{\mathbf{a}}$ & Percent \\
\hline No infection & $762 / 1,124$ & 68 \\
Single infection & & \\
GLRaV-1 & $113 / 1,124$ & 10 \\
GLRaV-2 & $36 / 1,124$ & 3 \\
GLRaV-3 & $173 / 1,124$ & 15 \\
Subtotal & $322 / 1,124$ & 29 \\
Multiple infection & & \\
GLRaV-1 + GLRaV-2 & $8 / 1,124$ & 0.7 \\
GLRaV-1 + GLRaV-3 & $28 / 1,124$ & 2.5 \\
GLRaV-2 + GLRaV-3 & $3 / 1,124$ & 0.3 \\
GLRaV-1 + GLRaV-2 + GLRaV-3 & $1 / 1,124$ & 0.1 \\
Subtotal & $40 / 1,124$ & 3.6 \\
\hline
\end{tabular}

${ }^{a}$ Infected samples were detected by double antibody sandwich-enzyme-linked immunosorbent assay. 
vines (Fig. 2, lanes 4 to 7). No viral DNA amplicon was obtained in total RNA from leaves of healthy vines, except a 183nucleotide-long RT-PCR product for the Vitis sp. Rbcl gene (Fig. 2).

DNA amplicons obtained by RT-PCR for three to five isolates of GLRaV-1, GLRaV-2, and GLRaV-3 each were sequenced directly. Nucleic acid sequences determined in this study were made available in GenBank as accession numbers FJ195739 to FJ195749. Sequence analysis confirmed the respective viral nature of RT-PCR products and indicated relatively high homologies of virus isolates characterized in this study and reference strains. Identities of 81.0 to $86.7 \%$ and 77.8 to $84.6 \%$ in the partial CPd2 gene of the type strain of GLRaV-1 (12), 87.6 to $99.2 \%$ and 92.6 to $97.8 \%$ in the partial CP gene of the type strain of GLRaV-2 (37), and 91.5 to $98.3 \%$ and 92.9 to $98.1 \%$ in the partial HSP70h gene of the type strain of GLRaV$3(22,23)$ were obtained at the nucleotide and amino acid levels, respectively.

Multiple sequence alignments indicated that three GLRaV-1, three GLRaV-2, and five GLRaV-3 isolates from New York and four GLRaV-1, 40 GLRaV-2, and 25 GLRaV-3 isolates from other geographic origins (Table 4) had 79.5 to $99 \%, 67.8$ to $100 \%$, and 74.1 to $100 \%$ identity at the nucleotide level, respectively; and 72.1 to $98.5 \%, 71.3$ to $100 \%$, and 85.9 to $100 \%$ identity at the amino acid level, respectively, in the CPd2 (GLRaV-1), CP (GLRaV-2), and HSP70h (GLRaV-3) genes, respectively.

Phylogenetic relationships among viral isolates were inferred using the neighborjoining method for a 205-nt portion of the GLRaV-1 CPd2 gene, a 345-nt fragment of the GLRaV-2 CP gene, and a 468-nt segment of the GLRaV-3 HSP70h gene (Fig. 3). The seven GLRaV-1 isolates clustered into three groups (Fig. 3A), the $43 \mathrm{GLRaV}-2$ isolates into six groups (Fig. $3 \mathrm{~B}$ ), and the $30 \mathrm{GLRaV}-3$ isolates into five groups (Fig. 3C). The same grouping of virus isolates was obtained with phylograms obtained from deduced amino acid sequences (68 aa of the GLRaV-1 CPd2, 115 aa of the GLRaV-2 CP, and 156 aa of the GLRaV-3 HSP70h) (data not shown).

The three GLRaV-1 isolates from New York clustered into two of the three phylogroups, including one with two isolates from $V$. vinifera $\mathrm{cv}$. Lemberger (Fig. 3A). The three GLRaV-2 isolates from New York clustered into the two predominant groups PN with isolates from Italy, Brazil, and the People's Republic of China, and $\mathrm{H} 4$ with isolates from Italy and Brazil (Fig. 3B). The five GLRaV-3 isolates from New York clustered into (i) the predominant group NY-1 with isolates from Europe, the Middle East, and the People's Republic of China, (ii) group GP18 with isolates from Austria, South Africa, and Syria, and (iii) group MT48-2 with isolates from Italy (Fig. 3C). Phylogenetic analyses further inferred no grouping of genetic variants based on Vitis sp. or geographical origin, except maybe for GLRaV-1 isolates from $V$. vinifera cv. Lemberger. However, the limited number of GLRaV-1 isolates for which sequence information is available in the CPd2 gene precludes any definite conclusion on an association between genetic variability and geographical origin or host. More sequence information would be

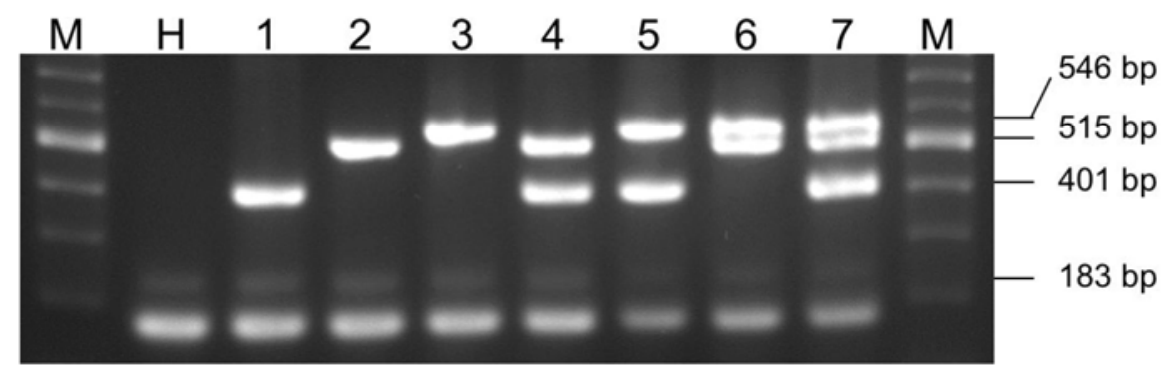

Fig. 2. Agarose gel analysis of DNA amplicons obtained by multiplex reverse transcriptionpolymerase chain reaction from total RNA of grapevine leaves infected by Grapevine leafrollassociated virus 1 (GLRaV-1), Grapevine leafroll-associated virus 2 (GLRaV-2), and Grapevine leafroll-associated virus 3 (GLRaV-3), and primer pairs specific to each virus and to the Vitis sp. Rbcl gene. Lane $\mathrm{H}$ : healthy $V$. vinifera $\mathrm{cv}$. Pinot noir; lane 1: V. vinifera $\mathrm{cv}$. Lemberger infected by GLRaV1; lane 2: V. vinifera cv. Chardonnay infected by GLRaV-2; lane 3: V. vinifera cv. Cabernet franc infected by GLRaV-3; lane 4: V. vinifera cv. Lemberger infected by GLRaV-1 and GLRaV-2; lane 5: $V$. vinifera $\mathrm{cv}$. Riesling infected by GLRaV-1 and GLRaV-3; lane 6: V. vinifera $\mathrm{cv}$. Pinot noir infected by GLRaV-2 and GLRaV-3; and lane 7: V. vinifera cv. Chardonnay infected by GLRaV-1, GLRaV-2, and GLRaV-3. Lanes M: 100 bp DNA size standard (Promega, Madison, WI). DNA products were resolved by electrophoresis on $2 \%$ agarose gels.

Table 4. Virus isolates used in this study to determine phylogenetic relationships

\begin{tabular}{|c|c|c|c|c|}
\hline Virus & Isolate & Cultivar & Country & GenBank accession no. \\
\hline GLRaV-1 & $\begin{array}{l}\text { B4L } \\
\text { Cf } \\
\text { 17NM1 } \\
21 \mathrm{KY} 1 \\
\text { Cs } \\
\text { Lem1 } \\
\text { Lem2 }\end{array}$ & $\begin{array}{l}\text { Sultana } \\
\text { Cabernet franc } \\
\text { Neo Muscat } \\
\text { Kyoho } \\
\text { Cabernet sauvignon } \\
\text { Lemberger } \\
\text { Lemberger }\end{array}$ & $\begin{array}{l}\text { Australia } \\
\text { P.R. China } \\
\text { Japan } \\
\text { Japan } \\
\text { United States } \\
\text { United States } \\
\text { United States }\end{array}$ & $\begin{array}{l}\text { AF195822 } \\
\text { EF583823 } \\
\text { AB222849 } \\
\text { AB222850 } \\
\text { FJ195739 } \\
\text { FJ195740 } \\
\text { FJ195741 }\end{array}$ \\
\hline GLRaV-2 & $\begin{array}{l}\text { PN } \\
\text { PnTM } \\
\text { Ch } \\
\text { Cf } \\
\text { Rei } \\
\text { L/I } \\
\text { IT } \\
\text { SE } \\
\text { Sg } \\
\text { Red1 } \\
\text { MuM } \\
\text { Mon } \\
\text { Arv2 } \\
\text { Tempr } \\
\text { Prim } \\
\text { Shandong } \\
\text { Isp } \\
\text { NA1 } \\
\text { NA2 } \\
\text { Red2 } \\
\text { SLIO } \\
\text { Tuc } \\
\text { 110R } \\
\text { 93/955 } \\
\text { Ner } \\
\text { Pol1 } \\
\text { Arv1 } \\
\text { Can } \\
\text { NerC } \\
\text { Pol2 } \\
\text { M/C } \\
\text { MH }\end{array}$ & $\begin{array}{l}\text { Pinot noir } \\
\text { Pinot noir } \\
\text { Chardonnay } \\
\text { Cabernet franc } \\
\text { Regina } \\
\text { Isabel } \\
\text { Italia } \\
\text { Seibel } \\
\text { Sangiovese } \\
\text { Red Globe } \\
\text { Muskat moransky } \\
\text { Montepulciano } \\
\text { Arvino } \\
\text { Tempranillo } \\
\text { Primitivo } \\
\text { Unknown } \\
\text { Isabella neva } \\
\text { Negro amoro } \\
\text { Negro amoro } \\
\text { Red Globe } \\
\text { Unknown } \\
\text { Tuccanese } \\
\text { 110R } \\
\text { LN33 } \\
\text { Nera } \\
\text { Pollera nera } \\
\text { Arvino } \\
\text { Cannonao } \\
\text { Nerello calabrese } \\
\text { Pollera nera } \\
\text { Concord } \\
\text { Muscat Hamburg }\end{array}$ & $\begin{array}{l}\text { United States } \\
\text { United States } \\
\text { United States } \\
\text { United States } \\
\text { Italy } \\
\text { Italy } \\
\text { Brazil } \\
\text { Brazil } \\
\text { Italy } \\
\text { Italy } \\
\text { Italy } \\
\text { Italy } \\
\text { Italy } \\
\text { Italy } \\
\text { Italy } \\
\text { P.R. China } \\
\text { Italy } \\
\text { Italy } \\
\text { Italy } \\
\text { Italy } \\
\text { P.R. China } \\
\text { Italy } \\
\text { Italy } \\
\text { South Africa } \\
\text { Italy } \\
\text { Italy } \\
\text { Italy } \\
\text { Italy } \\
\text { Italy } \\
\text { Italy } \\
\text { Brazil } \\
\text { Brazil }\end{array}$ & $\begin{array}{l}\text { AF039204 } \\
\text { FJ195742 } \\
\text { FJ195743 } \\
\text { FJ195744 } \\
\text { DQ314604 } \\
\text { EU053126 } \\
\text { EU204910 } \\
\text { EU204909 } \\
\text { DQ314607 } \\
\text { DQ314602 } \\
\text { DQ314594 } \\
\text { DQ314593 } \\
\text { DQ314590 } \\
\text { DQ314608 } \\
\text { DQ314601 } \\
\text { AY842932 } \\
\text { DQ314591 } \\
\text { DQ314595 } \\
\text { DQ314596 } \\
\text { DQ314603 } \\
\text { DQ911147 } \\
\text { DQ314609 } \\
\text { DQ314587 } \\
\text { AY842932 } \\
\text { DQ314598 } \\
\text { DQ314599 } \\
\text { DQ314588 } \\
\text { DQ314589 } \\
\text { DQ314597 } \\
\text { DQ314600 } \\
\text { EU053125 } \\
\text { EU204911 }\end{array}$ \\
\hline
\end{tabular}


needed to ascertain the phylogenetic relationships among GLRaV-1 isolates.

\section{DISCUSSION}

We report here the occurrence and prevalence of the three major viruses associated with grapevine leafroll disease in Finger Lakes vineyards in New York. The very high incidence of GLRaV-1, GLRaV2 , and GLRaV-3 in the majority of vineyard blocks surveyed indicates a poor sanitary status of planting materials. There is little doubt that the use of uncertified graftwood and/or rootstocks is the main, if not the single, reason for the widespread distribution of the three target viruses in the vineyard blocks surveyed. Vectormediated transmission cannot account for such an extensive virus distribution over the $2,500 \mathrm{~km}^{2}$ area surveyed. In recent years (2001 to 2006), the acreage of $V$. vinifera increased by $38 \%$ in the Finger Lakes region (36). As a result of many new plantings, there has been a $9 \%$ increase in $V$. vinifera production in New York, while the tonnage of V. labrusca and interspecific indicates that the sanitary status of vine stocks used to establish new vineyards or hybrids decreased by $6 \%$ (3). Our survey

the mother plants from which they derive received little oversight, stressing the need to reinstate a grapevine certification program in New York to improve the sanitary status of planting stocks.

Our study is the first to report the occurrence of GLRaV-1 in Finger Lakes vineyards. It also provides further evidence on the incidence of GLRaV-2 and GLRaV-3 in New York $(18,22,37,38)$. It is not too surprising to have found GLRaV-1, because this virus is prevalent in leafrollaffected $V$. vinifera along with GLRaV-2 and GLRaV-3 (13,37), and mixed viral infections are common in grapevines $(7,10,13,20)$. Target viruses were distributed similarly in $V$. vinifera and interspecific hybrids, indicating that the host genotype has limited, if any, effect on infection rates.

The presence of GLRaV-1, GLRaV-2, and GLRaV-3 was determined by DASELISA using specific antibodies. It was further ascertained in selected samples by RT-PCR using specific viral primers and a primer pair specific to the Vitis Rbc1 mRNA gene used as internal control. In a previous study, another set of primers was successfully used to amplify an 844-

Table 4. (continued from previous page)

\begin{tabular}{|c|c|c|c|c|}
\hline Virus & Isolate & Cultivar & Country & GenBank accession no. \\
\hline $\begin{array}{l}\text { GLRaV-2 } \\
\text { (cont.) }\end{array}$ & $\begin{array}{l}\text { RI } \\
\text { H4 } \\
\text { RG2 } \\
\text { RG } \\
\text { RG1 } \\
\text { PG11 } \\
\text { PV44 } \\
\text { BD } \\
\text { PV124 } \\
\text { PV20 } \\
\text { Leo }\end{array}$ & $\begin{array}{l}\text { Riesling } \\
\text { V. rupestris St George } \\
\text { Red Globe } \\
\text { Red Globe } \\
\text { Red Globe } \\
\text { Petit Meslier } \\
\text { Chardonnay } \\
\text { Dan Mariano } \\
\text { Negro Amoro } \\
\text { Savagnin } \\
\text { Leopold III }\end{array}$ & $\begin{array}{l}\text { Brazil } \\
\text { Italy } \\
\text { Italy } \\
\text { USA } \\
\text { Italy } \\
\text { France } \\
\text { France } \\
\text { Italy } \\
\text { France } \\
\text { France } \\
\text { Italy }\end{array}$ & $\begin{array}{l}\text { EU204912 } \\
\text { AY697863 } \\
\text { DQ314606 } \\
\text { AF314061 } \\
\text { DQ314605 } \\
\text { EF012720 } \\
\text { EF012718 } \\
\text { DQ286725 } \\
\text { EF012717 } \\
\text { EF012721 } \\
\text { DQ314592 }\end{array}$ \\
\hline GLRaV-3 & $\begin{array}{l}\text { NY1 } \\
\text { C3 } \\
\text { SY2-7 } \\
\text { MT48-1 } \\
\text { C4-1 } \\
\text { CfL } \\
\text { Ch } \\
\text { Ries } \\
\text { Mer } \\
\text { CfW } \\
\text { C6-1 } \\
\text { AUSG5-5 } \\
\text { SY2-2 } \\
\text { IL1 } \\
\text { MT48-4 } \\
\text { N1-1 } \\
\text { USA-6 } \\
\text { C1-1 } \\
\text { C3-1 } \\
\text { C2-1 } \\
\text { AUSG5-4 } \\
\text { Tu32 } \\
\text { C5-1 } \\
\text { SY2-4 } \\
\text { AUSG5-6 } \\
\text { GP18 } \\
\text { AUSG5-2 } \\
\text { MT48-2 } \\
\text { MT48-3 } \\
\text { NZ-1 }\end{array}$ & $\begin{array}{l}\text { Pinot noir } \\
\text { Fujihama } \\
\text { Homos } \\
\text { LN33 } \\
\text { Unknown } \\
\text { Cabernet franc } \\
\text { Chardonnay } \\
\text { Riesling } \\
\text { Merlot } \\
\text { Cabernet franc } \\
\text { Beta } \\
\text { Unknown } \\
\text { Homos } \\
\text { Hillmanis } \\
\text { LN33 } \\
\text { Unknown } \\
\text { Shermann } \\
\text { Unknown } \\
\text { Fujihama } \\
\text { Beta } \\
\text { Unknown } \\
\text { Unknown } \\
\text { Beta } \\
\text { Homos } \\
\text { Unknown } \\
\text { Cabernet sauvignon } \\
\text { Unknown } \\
\text { LN33 } \\
\text { LN33 } \\
\text { Unknown }\end{array}$ & $\begin{array}{l}\text { United States } \\
\text { R.P. China } \\
\text { Syria } \\
\text { Italy } \\
\text { United States } \\
\text { United States } \\
\text { United States } \\
\text { United States } \\
\text { United States } \\
\text { United States } \\
\text { P.R. China } \\
\text { Austria } \\
\text { Syria } \\
\text { Israël } \\
\text { Italy } \\
\text { United States } \\
\text { United States } \\
\text { United States } \\
\text { P.R. China } \\
\text { P.R. China } \\
\text { Austria } \\
\text { Tunisia } \\
\text { P.R. China } \\
\text { Syria } \\
\text { Austria } \\
\text { South Africa } \\
\text { Austria } \\
\text { Italy } \\
\text { Italy } \\
\text { New Zealand }\end{array}$ & $\begin{array}{l}\text { AF039204 } \\
\text { AJ748514 } \\
\text { AJ748517 } \\
\text { AJ748518 } \\
\text { DQ780888 } \\
\text { FJ195745 } \\
\text { FJ195746 } \\
\text { FJ195747 } \\
\text { FJ195748 } \\
\text { FJ195749 } \\
\text { DQ780890 } \\
\text { AJ748512 } \\
\text { AJ748515 } \\
\text { AJ748524 } \\
\text { AJ748521 } \\
\text { DQ780891 } \\
\text { AJ748523 } \\
\text { DQ780885 } \\
\text { DQ780887 } \\
\text { DQ780886 } \\
\text { AJ748511 } \\
\text { AJ748522 } \\
\text { DQ780889 } \\
\text { AJ748516 } \\
\text { AJ748513 } \\
\text { EU259806 } \\
\text { AJ748510 } \\
\text { AJ748519 } \\
\text { AJ748520 } \\
\text { EF508151 }\end{array}$ \\
\hline
\end{tabular}

nucleotide-long Vitis 18S ribosomal RNA as internal control in RT-PCR assays for the simultaneous detection of nine grapevine viruses (14). The Rbcl genes of $V$. vinifera (complete sequence NC_007957.1) and Prunus persica (partial sequence AF2066813) have 95.6\% nucleotide identity (M. Fuchs, unpublished). This high homology enabled us to design primers based on those used as internal control for virus detection by RT-PCR in Prunus (31). The use of primers specific to the Rbc1 gene mRNA allowed us to determine the effectiveness of RT-PCR and assess directly the quality of total RNA from grapevine leaves without electrophoresis on denaturing gels, among other techniques.

Analyses of partial gene sequences revealed a close relationship of GLRaV-1, GLRaV-2, and GLRaV-3 isolates from New York and other isolates from various geographical origins. These data are consistent with the fact that transmission of these viruses occurs predominantly through uncontrolled exchange and propagation of budwood material. Furthermore, we found no relationship between genetic variability of the target viruses and geographic origin or host genotype. These data confirm previous observations for GLRaV-1 (21,24), GLRaV-2 (2,5,6,29), and GLRaV-3 $(19,34)$.

The fact that GLRaV-1 and GLRaV-3 can be transmitted between and within vineyard blocks by soft scale and mealybug species $(17,25,27,32)$ emphasizes the need to assess whether indigenous insect populations can act as vectors in Finger Lakes vineyards. Spread of leafrollassociated viruses can be rapid, especially for GLRaV-3, resulting in new vineyard infection within a few years (9). Also, a single mealybug nymph is capable of infecting a healthy grapevine with GLRaV-3 (11). Since mealybugs and soft scales transmit GLRaV-3 in Australia, France, Israel, Italy, Greece, New Zealand, South Africa, Spain, Tunisia, and the United States, including California and Washington $(16,17,27,28)$, it is conceivable that GLRaV-3 might spread similarly in New York. The same assumption holds true for GLRaV-1. Experiments to assess the transmissibility of GLRaV-1 and GLRaV-3 by soft scales and mealybugs in Finger Lakes vineyards are under way. These studies are critical to determine if pest management strategies need to be deployed for vectors of leafroll-associated viruses or if a certification program should be effective in controlling these viruses.

\section{ACKNOWLEDGMENTS}

The collaboration of 25 grape growers in the Finger Lakes region in New York is acknowledged. We are grateful to Bill Wilsey, Patricia MarsellaHerrick, Rosemary Cox, Aracely Ospina, Eric Rockefeller, Yen Mei Cheung, Hussein Alzubi, Tania Krastanova, Jonathan Oliver, Hans WalterPetersen, and Jamie Hawk for sample collection and processing. We are indebted to L. M. Yepes for 
A

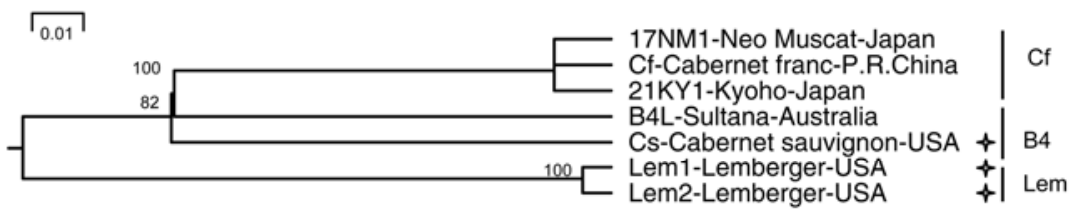

B

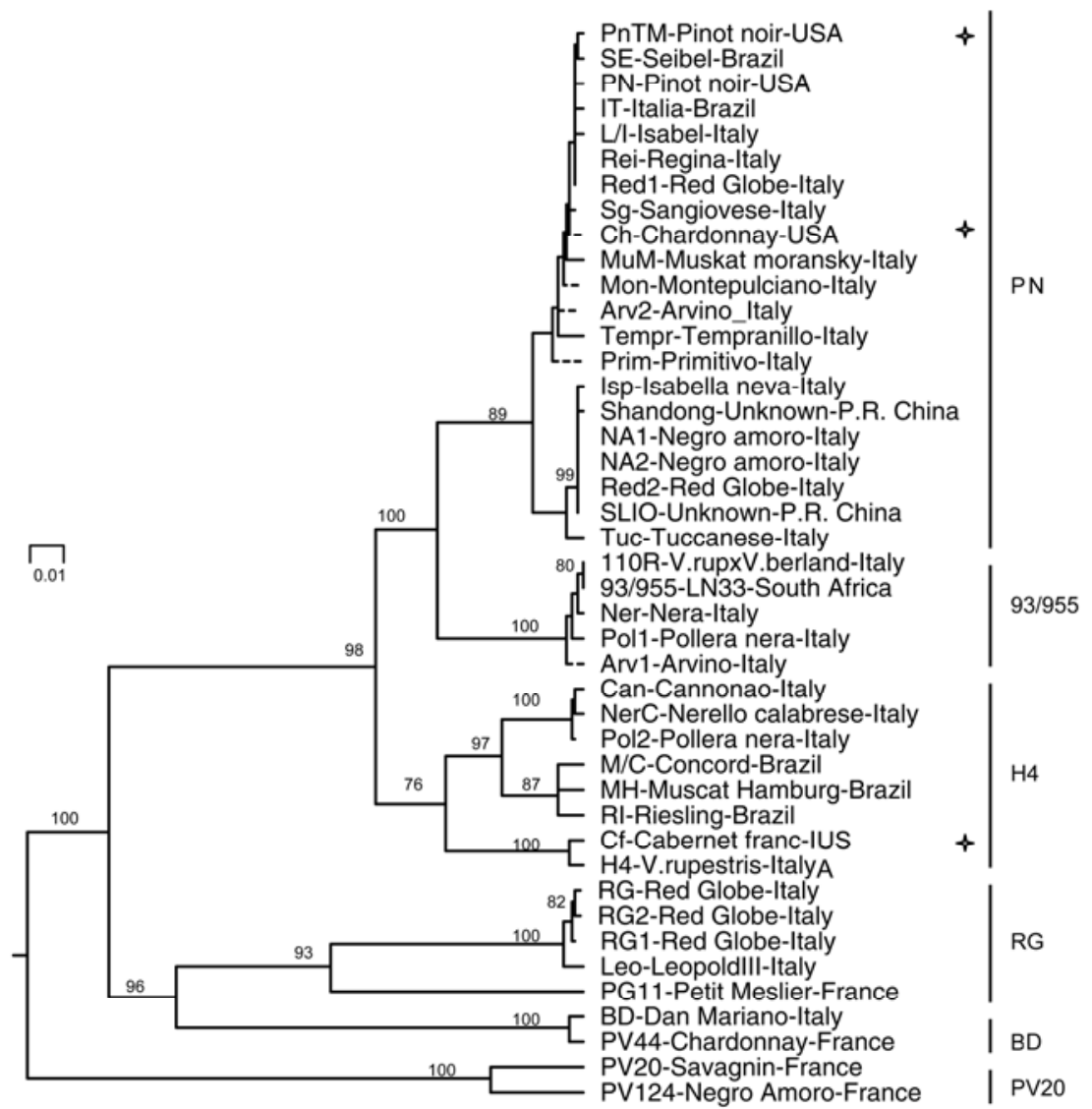

C

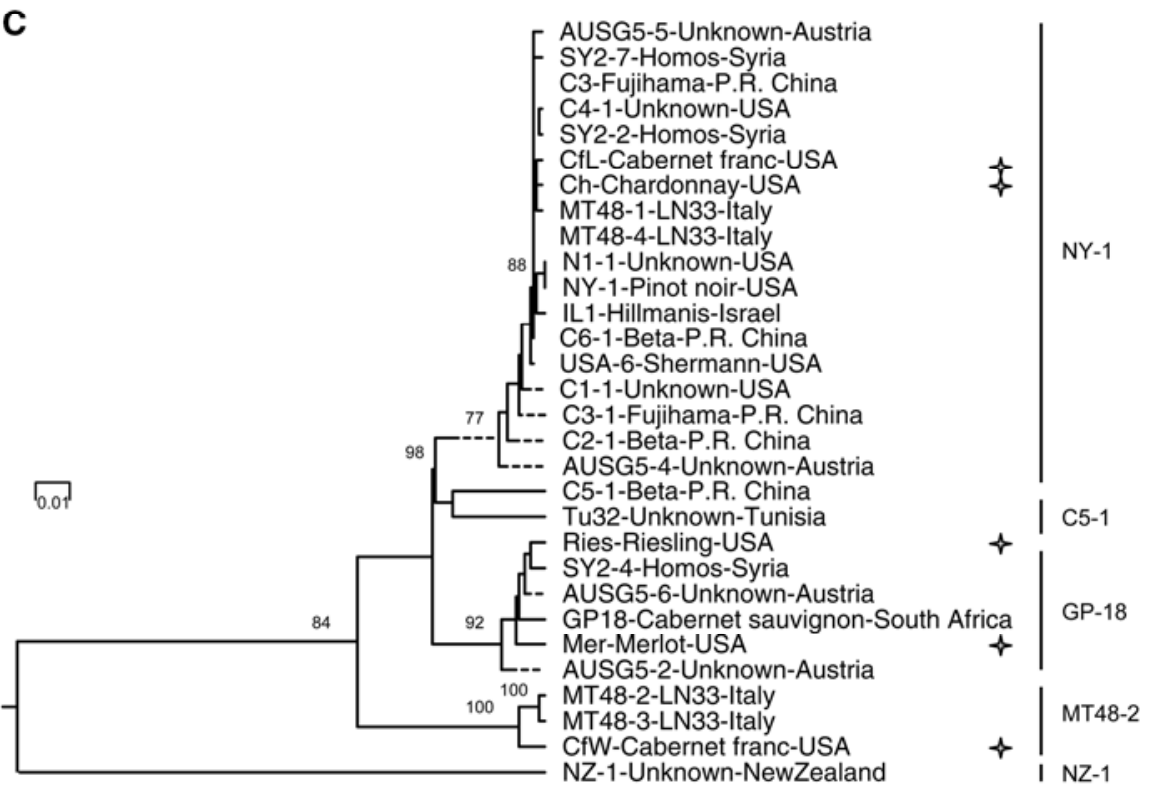

Fig. 3. Phylogenetic trees reconstructed from partial nucleotide sequences of A, CPd2 gene of Grapevine leafroll-associated virus 1 (GLRaV-1), B, CP gene of Grapevine leafroll-associated virus 2 (GLRaV-2), and C, HSP70h gene of Grapevine leafroll-associated virus 3 (GLRaV-3) isolates by the neighbor-joining method with 1,000 bootstrap replicates. Branch length represents phylogenetic distances determined with distance matrices of nucleotide sequences. Numbers above critical branches are significant bootstrap values $(>75 \%)$. Scale bar represents a relative genetic distance of 0.01 . Representative isolates of each phylogroup are indicated as well as the country of origin for each sequence accession. GLRaV isolates sequenced in this study are indicated by stars. critically reading the manuscript. This study was partially funded by USDA-CSREES Viticulture Consortium-East, New York State Wine and Grape Foundation, Lake Erie Regional Grape Program, and state, federal, and institutional funds appropriated to the New York State Agricultural Experiment Station, Cornell University.

\section{LITERATURE CITED}

1. Abou Ghanem-Sabanadzovic, N., Sabanadzovic, S., Uyemoto, J. K., and Rowhani, A. 2006. A putative new ampelovirus associated with grapevine leafroll disease. In: Proc. 15th Meeting International Council Study Virus Virus-like Diseases Grapevine. Online: http:// www.icvg.ch/data/extabstr2006part1.pdf.

2. Angelini, E., Bertazzon, N., and Borgo, M. 2004. Diversity of grapevine leafrollassociated virus 2 isolates detected by heteroduplex mobility assay. J. Phytopatol. 152:416422.

3. Anonymous. 2008. Fruit Tree and Vineyard Survey. New York Agriculture Statistics Service. http://www.nass.usda.gov/Statistics_by_ State/New_York/Publications/Statistical_Repo rts/03mar/Fruit\%20Tree\%200208.htm.

4. Bertazzon, N., and Angelini, E. 2004. Advance on the detection of Grapevine leafrollassociated virus 2 variants. J. Plant Pathol. 86:283-290.

5. Bertazzon, N., Angelini, E., and Borgo, M. 2006. Characterization of Grapevine leafrollassociated virus 2 strain BD. In: Proc. 15th Meeting International Council Study Virus Virus-Like Diseases Grapevine. Online: http:// www.icvg.ch/data/extabstr2006part1.pdf.

6. Beuve, M., Sempé, L., and Lemaire, O. 2007. A sensitive one-step real-time RT-PCR method for detecting Grapevine leafroll-associated virus 2 variants in grapevine. J. Virol. Methods 141:117-124.

7. Borgo, M., Angelini, E., Costacurta, A., and Scalabrelli, G. 2005. Preservation and protection of genetic resources of autochthonous varieties in central Italy: Occurrence of viroses. Bulletin OIV 887-888:17-29.

8. Bovey, R., Gärtel, W., Hewitt, W. B., Martelli, G. P., and Vuittenez, A. 1980. Virus without known vectors. Pages 51-52 in: Virus and Virus-like Diseases of Grapevines. R. Bovey, W. Gärtel, W. B. Hewitt, G. P. Martelli, and A. Vuittenez, eds. Editions Payot, Lausanne, Switzerland.

9. Cabaleiro, C., Couceiro, C., Pereira, S., Cid, M., Barrasa, M., and Segura, A. 2008. Spatial analysis of epidemics of Grapevine leafroll associated virus-3. Eur. J. Plant Pathol. 121:121130.

10. Credi, R., and Babini, A. R. 1997. Effects of virus and virus-like infections on growth, yield, and fruit quality of Albana and Trebbiano Romagnolo grapevines. Am. J. Enol. Vitic. 48:7-12.

11. Douglas, N., and Krüger, K. 2008. Transmission efficiency of Grapevine leafroll-associated virus 3 (GLRaV-3) by the mealybug Planococcus ficus and Pseudococcus longispinus (Hemiptera: Pseudococcidae). Eur. J. Plant Pathol. 122:207-212.

12. Fazeli, C. F., and Rezaian, M. A. 2000. Nucleotide sequence and organization of ten open reading frames in the genome of Grapevine leafroll-associated virus 1 and identification of three subgenomic RNAs. J. Gen. Virol. 81:605-615.

13. Fiore, N., Prodan, S., Montealegre, J., Aballay, E., Pino, A. M., and Zamorano, A. 2008. Survey of grapevine viruses in Chile. J. Plant Pathol. 90:125-130.

14. Gambino, G., and Gribaudo, I. 2006. Simultaneous detection of nine grapevine viruses by multiplex reverse transcription-polymerase chain reaction with coamplification of a plant RNA as internal control. Phytopathology 
96:1223-1229.

15. Goheen, A. C. 1990. Leafroll. Page 52 in: Compendium of Grape Diseases. R. Pearson and A.C. Goheen, eds. American Phytopathological Society, St Paul, MN.

16. Golino, D. A., Sim, S. T., Gill, R., and Rowhani, A. 2002. California mealybugs can spread grapevine leafroll disease. Calif. Agric. 56:196-201.

17. Gugerli, P. 2003. Grapevine leafroll and related viruses. In: Proc. 14th Meeting International Council Study Virus Virus-Like Diseases Grapevine.

Online: http://www.agr.uniba.it/ICVG2003.

18. Hu, J. S., Gonsalves, D., and Teliz, D. 1990. Characterization of closterovirus-like particles associated with grapevine leafroll disease. J. Phytopathol. 128:1-14.

19. Jooste, A. E. C., and Goszczynski, D. E. 2005. Single-stranded confirmation polymorphism (SSCP), cloning and sequencing reveal two major groups of divergent molecular variants of grapevine leafroll-associated virus 2 (GLRaV-3). Vitis 44:39-43.

20. Komar, V., Vigne, E., Demangeat, G., and Fuchs, M. 2007. Beneficial effect of selective virus elimination on the performance of Vitis vinifera cv. Chardonnay. Am. J. Enol. Vitic. 58:202-210.

21. Kominek, P., Glasa, M., and Bryxiova, M. 2005. Analysis of the molecular variability of Grapevine leafroll-associated virus 1 reveals the presence of two distinct virus groups and their mixed occurrence in grapevines. Virus Genes 31:247-255.

22. Ling, K. S., Zhu, H. Y., Drong, R. F., Slightom, J. L., McFerson, J. R., and Gonsalves, D. 1998. Nucleotide sequence of the $3^{\prime}$-terminal two-thirds of the grapevine leafroll-associated virus-3 genome reveals a typical monopartite closterovirus. J. Gen. Virol. 79:1299-1307.
23. Ling, K. S., Zhu, H. Y., and Gonsalves, D. 2004. Complete nucleotide sequence and genome organization of Grapevine leafrollassociated virus 3, type member of the genus Ampelovirus. J. Gen. Virol. 85:2099-2102.

24. Little, A., Fazeli, C. F., and Rezaian, M. A. 2001. Hypervariable genes in grapevine leafroll associated virus 1. Virus Res. 80:109116.

25. Martelli, G. P. 1993. Graft-transmissible diseases of grapevines. Handbook for Detection and Diagnosis. FAO Publication Division, Rome, Italy.

26. Martelli, G. P. 2006. Grapevine virology highlights 2004-2005. In: Proc. 15th Meeting International Council Study Virus Virus-like Diseases Grapevine. http://www.icvg.ch/data/ext abstr2006part1.pdf.

27. Martelli, G. P., and Boudon-Padieu, E. 2006. Directory of infectious diseases of grapevines. International Centre for Advanced Mediterranean Agronomic Studies. Options Méditerranéennes Ser. B, Studies and Research 55:5975 .

28. Martin, R. R., Eastwell, K. C., Wagner, A., Lamprecht, S., and Tzanetakis, I. E. 2005. Survey for viruses of grapevine in Oregon and Washington. Plant Dis. 89:763-766.

29. Meng, B., Li, C., Goszczynski, D. E., and Gonsalves, D. 2005. Genome sequences and structures of two biologically distinct strains of Grapevine leafroll-associated virus 2 and sequence analysis. Virus Genes 31:31-41.

30. Saitou, N., and Nei, M. 1987. The neighborjoining method: A new method for reconstructing phylogenetic trees. Mol. Biol. Evol. 4:406425.

31. Sanchez-Navarro, J. A., Aparicio, F., Herranz, M. C., Minafra, A., Myrta, A., and Pallas, V. 2005. Simultaneous detection and identification of eight stone fruit viruses by one-step RT-
PCR. Eur. J. Plant Pathol. 111:77-84.

32. Scorza, R., Boudon-Padieu, E., and Greif, C. 2003. New mealybug species vectoring Grapevine leafroll-associated viruses-1 and -3 (GLRaV-1 and -3). Eur. J. Plant Pathol. 109:975.

33. Thompson, J. D., Higgins, D. J., and Gibson, T. J. 1994. CLUSTAL W: Improving the sensi tivity of progressive multiple sequence alignment through sequence weighting, positionspecific gap penalties and weight matrix choice. Nucleic Acids Res. 22:4673-4680.

34. Turturo, C., Saldarelli, P., Yafeng, D., Digiaro, M., Minafra, A., Savino, V., and Martelli, G. P. 2005. Genetic variability and population structure of Grapevine leafroll-associated virus 3 isolates. J. Gen. Virol. 86:217-224.

35. Walter, B., and Etienne, L. 1987. Detection of the grapevine fanleaf viruses away from the period of vegetation. J. Phytopathol. 120:355364.

36. White, G. B. 2008. Cost of establishment and production of Vinifera grapes in the Finger Lakes region of New York. Publications, Department of Applied Economics and Management, Cornell University, Ithaca, NY.

37. Wilcox, W. F., Jiang, Z.-Y., and Gonsalves, D. 1998. Leafroll virus is common in cultivated American grapevines in western New York. Plant Dis. 82:1062.

38. Zhu, H. Y., Ling, K. S., Goszczynski, D. E. McFerson, J. R., and Gonsalves, D. 1998. Nucleotide sequence and genome organization of grapevine leafroll-associated virus- 2 are similar to beet yellows virus, the closterovirus type member. J. Gen. Virol. 79:1289-1298.

39. Zimmermann, D., Bass, P., Legin, R., and Walter, B. 1990. Characterization and serological detection of four closterovirus-like particles associated with leafroll disease on grapevine. J. Phytopathol. 130:205-218. 